\title{
Griffithsin and Carrageenan Combination Results in Antiviral Synergy against SARS-CoV-1 and 2 in a Pseudoviral Model
}

\author{
Sahar Alsaidi ${ }^{1,2,3, \dagger}$, Nadjet Cornejal ${ }^{1,2,4, \dagger}$, Oneil Mahoney ${ }^{1,2}$, Claudia Melo ${ }^{1,2,4} \mathbb{C}^{\mathbb{D}}$, Neeharika Verma ${ }^{1}$, \\ Thierry Bonnaire ${ }^{1}$, Theresa Chang ${ }^{5}{ }^{\oplus}$, Barry R. O'Keefe ${ }^{6}{ }^{\oplus}$, James Sailer ${ }^{1}$, Thomas M. Zydowsky ${ }^{1}$, \\ Natalia Teleshova ${ }^{1}$ and José A. Fernández Romero ${ }^{1,2, *(1)}$
}

Citation: Alsaidi, S.; Cornejal, N.; Mahoney, O.; Melo, C.; Verma, N.; Bonnaire, T.; Chang, T.; O'Keefe, B.R.; Sailer, J.; Zydowsky, T.M.; et al. Griffithsin and Carrageenan Combination Results in Antiviral Synergy against SARS-CoV-1 and 2 in a Pseudoviral Model. Mar. Drugs 2021, 19, 418. https://doi.org/ $10.3390 / \mathrm{md} 19080418$

Academic Editor:

Orazio Taglialatela-Scafati

Received: 12 June 2021

Accepted: 23 July 2021

Published: 26 July 2021

Publisher's Note: MDPI stays neutral with regard to jurisdictional claims in published maps and institutional affiliations.

Copyright: (C) 2021 by the authors Licensee MDPI, Basel, Switzerland. This article is an open access article distributed under the terms and conditions of the Creative Commons Attribution (CC BY) license (https:// creativecommons.org/licenses/by/ $4.0 /)$.
1 Population Council, New York, NY 10065, USA; sahar.alsaidi@lc.cuny.edu (S.A.); nadjet.cornejal96@bcmail.cuny.edu (N.C.); oneil.mahoney@stu.bmcc.cuny.edu (O.M.); claudia.melo24@bcmail.cuny.edu (C.M.); nverma@popcouncil.org (N.V.); tbonnaire@popcouncil.org (T.B.); jsailer@popcouncil.org (J.S.); tzydowsky@popcouncil.org (T.M.Z.); nteleshova@popcouncil.org (N.T.)

2 Department of Science, Borough of Manhattan Community College, The City University of New York, New York, NY 10007, USA

3 Department of Anthropology, Lehman College, The City University of New York, New York, NY 10468, USA

4 Center for Achievement in Science Education, Department of Biology and Chemistry, School of Natural and Behavioral Sciences, Brooklyn College, The City University of New York, New York, NY 11210, USA

5 Department of Microbiology, Biochemistry and Molecular Genetics, New Jersey Medical School, Rutgers, The State University of New Jersey, Newark, NJ 07102, USA; changth@njms.rutgers.edu

6 Natural Products Branch, Molecular Targets Program, Developmental Therapeutics Program, Center for Cancer Research, Division of Cancer Treatment and Diagnosis, National Cancer Institute, Frederick, MD 21702, USA; okeefeba@mail.nih.gov

* Correspondence: jfernandezromero@bmcc.cuny.edu

+ These authors contributed equally to this work.

Abstract: Over 182 million confirmed cases of COVID-19 and more than 4 million deaths have been reported to date around the world. It is essential to identify broad-spectrum antiviral agents that may prevent or treat infections by severe acute respiratory syndrome coronavirus 2 (SARS-CoV-2) but also by other coronaviruses that may jump the species barrier in the future. We evaluated the antiviral selectivity of griffithsin and sulfated and non-sulfated polysaccharides against SARS-CoV-1 and SARS-CoV-2 using a cytotoxicity assay and a cell-based pseudoviral model. The half-maximal cytotoxic concentration $\left(\mathrm{CC}_{50}\right)$ and half-maximal effective concentration $\left(\mathrm{EC}_{50}\right)$ were determined for each compound, using a dose-response-inhibition analysis on GraphPad Prism v9.0.2 software (San Diego, CA, USA). The therapeutic index $\left(\mathrm{TI}=\mathrm{CC}_{50} / \mathrm{EC}_{50}\right.$ ) was calculated for each compound. The potential synergistic, additive, or antagonistic effect of different compound combinations was determined by CalcuSyn v1 software (Biosoft, Cambridge, UK), which estimated the combination index $(\mathrm{CI})$ values. Iota and lambda carrageenan showed the most potent antiviral activity $\left(\mathrm{EC}_{50}\right.$ between 3.2 and $7.5 \mu \mathrm{g} / \mathrm{mL}$ ). Carrageenan and griffithsin combinations exhibited synergistic activity ( $\mathrm{EC}_{50}$ between 0.2 and $3.8 \mu \mathrm{g} / \mathrm{mL}$; combination index $<1$ ), including against recent SARS-CoV-2 mutations. The griffithsin and carrageenan combination is a promising candidate to prevent or treat infections by SARS-CoV-1 and SARS-CoV-2.

Keywords: SARS-CoV-1; SARS-CoV-2; lectins; sulfated polysaccharides

\section{Introduction}

The emergence of a novel coronavirus, quickly escalated into the current pandemic that was declared on 11 March 2020, by the World Health Organization. The pandemic has placed healthcare systems under extreme pressure; globally, over 182 million confirmed cases of COVID-19 and more than 4 million deaths have been reported to date [1]. The novel virus, severe acute respiratory syndrome coronavirus 2 (SARS-CoV-2), belongs to the Coronaviridae family. This family includes SARS-CoV-1 and MERS-CoV, two zoonotic 
viruses that emerged in 2003 and 2012, respectively [2]. Although highly effective vaccines targeting SARS-CoV-2 spike proteins have been approved for emergency use by multiple stringent regulatory authorities, accumulation of mutations in the spike protein may allow the virus to be transmitted more effectively and, in the worst-case scenario, evade the immune response triggered by vaccines [3-6].

The coronaviruses have shown an impressive ability to jump the species barrier, and more coronaviruses may migrate from animal reservoirs to humans in the future. For these reasons, it is essential to identify broad-spectrum antiviral agents that inhibit different coronaviruses and help to prevent/treat the diseases caused by these viruses. SARS-CoV-1 and SARS-CoV-2 have a similar natural history of infection; both enter the upper respiratory tract and infect the epithelial cells lining the respiratory tract. They enter target cells by binding of their surface spike proteins to human angiotensin-converting enzyme 2 (ACE2), the primary viral receptor, present on the surface of target cells [7]. Therefore, antiviral agents that target SARS-CoV-1 and SARS-CoV-2 entry have the potential to prevent/treat these infections.

Naturally occurring antiviral agents, such as griffithsin (GRFT, Figure 1A), an antiviral lectin, and carrageenan (CG, Figure 1B), a sulfated polysaccharide, can target a wide range of enveloped viruses [8]. Importantly, GRFT has previously been reported to have broadspectrum in vitro activity against Coronaviridae and in vivo activity against SARS-CoV-1 in a mouse model system following intranasal administration [9]. Similarly, the activity of sulfated polysaccharides against SARS-CoV-2 is documented in the literature [10,11].

A

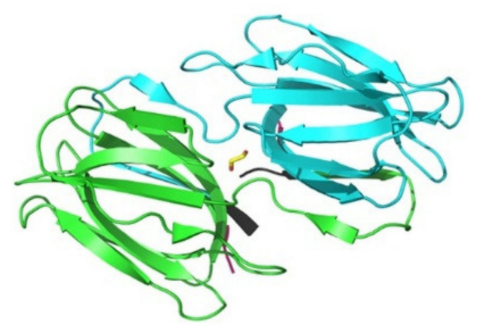

B
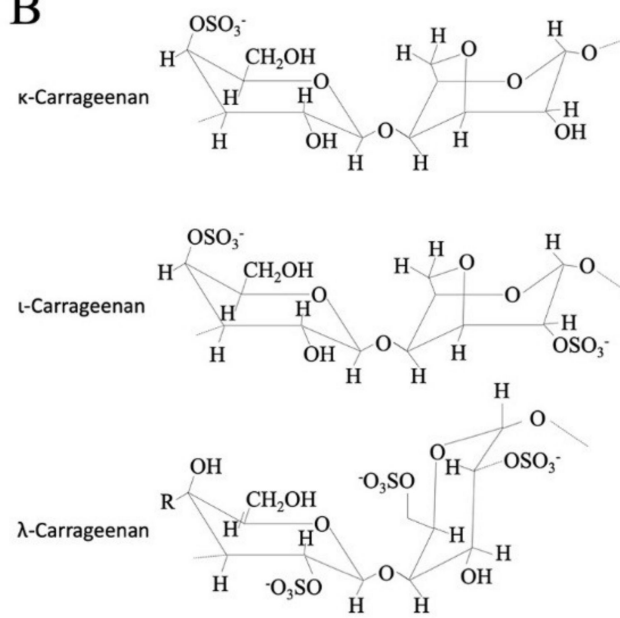

Figure 1. The structure of GRFT and CG. (A) The homodimeric native structure of GRFT (adapted from Moulaei et al. [12]). (B) The sulfated polysaccharides k-Carrageenan ( $\mathrm{k}-\mathrm{CG})$, $\mathrm{l}-\mathrm{Carrageenan}$ $(\mathrm{t}-\mathrm{CG})$, and $\lambda$-Carrageenan $(\lambda-\mathrm{CG})$.

GRFT is a homodimeric lectin of 121 aminoacids and six carbohydrate-binding sites with high affinity for high mannose arrays. These mannose arrays are frequently found in viral spikes of important pathogens like HIV, HSV, hepatitis C virus (HCV), ebola virus, and members of the Coronaviridae family [13]. The ability to block HIV in vitro, at picomolar concentrations, makes GRFT one of the most potent molecules inhibiting HIV replication [14]. Although $\mathrm{EC}_{50}$ values are higher against coronaviruses, GRFT is potent enough to make this naturally occurring agent a promising candidate to fight the current SARS-CoV-2 pandemic. In addition to the drug potency, GRFT is poorly immunogenic, and several studies in animal models have shown its excellent safety profile [15]. CGs are polysaccharides isolated from red seaweed; its broad antiviral spectrum includes viruses like HSV, rhinoviruses, and coronaviruses. The antiviral activity is well-documented against HPV and is probably the most potent anti-HPV agent reported in the literature [16,17]. Several preclinical and clinical studies have shown its excellent safety profile after vaginal and 
respiratory routes of administration [18,19]. Additionally, CG is Generally Recognized as Safe (GRAS) by the Food and Drug Administration and is a common food additive [20]. Herein, we further explore the potential antiviral selectivity of GRFT, non-sulfated and sulfated polysaccharides, and combinations thereof against SARS-CoV-1 and SARS-CoV-2.

\section{Results}

Table 1 shows the half-maximal cytotoxic concentration $\left(\mathrm{CC}_{50}\right)$, half-maximal effective concentration $\left(\mathrm{EC}_{50}\right)$, and therapeutic index (TI) values for all the compounds tested. GRFT showed broad-spectrum antiviral activity against SARS-CoV-1 and 2. While the polysaccharides with selective antiviral activity were all sulfated, the sulfate group's presence is not a determining factor of the efficacy; some sulfated polysaccharides, such as heparin, heparan sulfate, fucoidan, and chondroitin sulfate did not show antiviral activity against SARS-CoV-1 or SARS-CoV-2. Among the polysaccharides, $\mathrm{l}-\mathrm{CG}$ and $\lambda-\mathrm{CG}$ had the best activity, with $\mathrm{EC}_{50}$ values below $7.5 \mu \mathrm{g} / \mathrm{mL}$. Therefore, we focused on $\mathrm{t}-\mathrm{CG}$ and $\lambda-\mathrm{CG}$, evaluating their combination with GRFT. Previous studies have shown the GRFT and CG combination results in synergistic or additive effects against different viruses including HPV and HSV [8]. The potential synergistic effect of the GRFT and CG combination against SARS-CoV-1 and SARS-CoV-2 was determined by CalcuSyn software (Biosoft, Cambridge), which estimated the combination index (CI) values. As shown in Table 2, $\mathrm{t}-\mathrm{CG}$ and $\lambda$-CG inhibited entry of SARS-CoV-1 and all SARS-CoV-2 PsVs with lower EC $_{50}$ values (between 3.2 and $7.5 \mu \mathrm{g} / \mathrm{mL}$ ) than those shown by GRFT (between 12.5 and $37.6 \mu \mathrm{g} / \mathrm{mL}$ ). The $\mathrm{EC}_{50}$ of GRFT against all three SARS-CoV-2 PsVs was larger when compared to SARS-CoV-1 PsV. However, some of the most relevant mutations recently identified in the SARS-CoV-2 spike protein (D614G, K1417N/E484K/N501Y), did not significantly impact the susceptibility of these PsVs to GRFT. Interestingly, GRFT/CG combinations showed more potent antiviral activity, specially at a 5:1 ratio, as indicated by the lower $\mathrm{EC}_{50}$ values in Table 2 . The data also revealed their synergistic activity, based on CI values below 1 .

Table 1. Selective antiviral activity of GRFT, sulfated and non-sulfated polysaccharides against SARS-CoV-1 and SARS-CoV-2 Wuhan PsVs.

\begin{tabular}{|c|c|c|c|c|c|c|c|c|}
\hline \multirow{2}{*}{ Compounds } & \multirow{2}{*}{ Category } & \multirow{2}{*}{$\begin{array}{c}\text { Molecular } \\
\text { Weight (kDa) }\end{array}$} & \multirow{2}{*}{ Source } & \multirow{2}{*}{$\frac{\mathrm{CC}_{50}{ }^{+}}{(\mu \mathrm{g} / \mathrm{mL})}$} & \multicolumn{2}{|c|}{$\mathrm{EC}_{50}{ }^{\mathrm{I}}(\mu \mathrm{g} / \mathrm{mL})$} & \multicolumn{2}{|c|}{$\mathrm{TI}^{*}$} \\
\hline & & & & & SARS-1 ${ }^{\S}$ & SARS-2 ${ }^{\S}$ & SARS-1 ${ }^{\S}$ & SARS-2 $\$$ \\
\hline $\begin{array}{l}\text { Griffithsin } \\
\text { (GRFT) }\end{array}$ & Lectin & 12.77 & $\begin{array}{c}\text { Custom } \\
\text { manufactured } \\
{[14]}\end{array}$ & $>600$ & 12.5 & 20.6 & $>48$ & $>29$ \\
\hline $\begin{array}{c}\lambda \text {-Carrageenan } \\
(\lambda-C G)\end{array}$ & $\begin{array}{c}\text { Sulfated } \\
\text { polysaccharide }\end{array}$ & $600-700$ & $\begin{array}{c}\text { Gelymar } \\
\text { (Santiago de } \\
\text { Chile, Chile) }\end{array}$ & $>600$ & 4.2 & 6.1 & $>143$ & $>98$ \\
\hline $\begin{array}{l}\text { ı-Carrageenan } \\
\quad(\mathrm{t}-\mathrm{CG})\end{array}$ & $\begin{array}{c}\text { Sulfated } \\
\text { polysaccharide }\end{array}$ & $400-560$ & $\begin{array}{c}\text { Gelymar } \\
\text { (Santiago de } \\
\text { Chile, Chile) }\end{array}$ & $>600$ & 4.3 & 7.5 & $>139$ & $>80$ \\
\hline $\begin{array}{c}\text { к-Carrageenan } \\
(\text { k-CG) }\end{array}$ & $\begin{array}{c}\text { Sulfated } \\
\text { polysaccharide }\end{array}$ & $400-560$ & $\begin{array}{c}\text { Sigma Aldrich } \\
\text { (St. Louis, MO, } \\
\text { USA) }\end{array}$ & $>600$ & 8.4 & 24.2 & $>71$ & $>25$ \\
\hline Dextran sulfate & $\begin{array}{c}\text { Sulfated } \\
\text { polysaccharide }\end{array}$ & $\sim 15$ & $\begin{array}{c}\text { Sigma Aldrich } \\
\text { (St. Louis, MO, } \\
\text { USA) }\end{array}$ & $>600$ & 7.8 & 19.4 & $>77$ & $>31$ \\
\hline $\begin{array}{l}\text { Lignosulfonic } \\
\text { acid }\end{array}$ & $\begin{array}{c}\text { Polar } \\
\text { lignin-derived }\end{array}$ & 52 & $\begin{array}{c}\text { Beantown } \\
\text { Chemical Corp. } \\
\text { (Hudson, NH, } \\
\text { USA) }\end{array}$ & $>600$ & 93.9 & 184.4 & $>6$ & $>3$ \\
\hline Heparan sulfate & $\begin{array}{c}\text { Sulfated } \\
\text { polysaccharide }\end{array}$ & $\sim 30$ & $\begin{array}{c}\text { Sigma Aldrich } \\
\text { (St. Louis, MO, } \\
\text { USA) }\end{array}$ & $>600$ & $>600$ & $>600$ & ND & ND \\
\hline
\end{tabular}


Table 1. Cont.

\begin{tabular}{|c|c|c|c|c|c|c|c|c|}
\hline \multirow{2}{*}{ Compounds } & \multirow{2}{*}{ Category } & \multirow{2}{*}{$\begin{array}{c}\text { Molecular } \\
\text { Weight (kDa) }\end{array}$} & \multirow{2}{*}{ Source } & \multirow{2}{*}{$\begin{array}{c}\mathrm{CC}_{50}{ }^{\dagger} \\
(\mu \mathrm{g} / \mathrm{mL})\end{array}$} & \multicolumn{2}{|c|}{$\mathrm{EC}_{50}{ }^{\mathrm{II}}(\mu \mathrm{g} / \mathrm{mL})$} & \multicolumn{2}{|c|}{$\mathrm{TI}^{*}$} \\
\hline & & & & & SARS-1 $§$ & SARS-2 $\S$ & SARS-1 ${ }^{\S}$ & SARS-2 $\$$ \\
\hline $\begin{array}{l}\text { Chondroitin } \\
\text { sulfate }\end{array}$ & $\begin{array}{c}\text { Sulfated } \\
\text { polysaccharide }\end{array}$ & $14-26$ & $\begin{array}{l}\text { Sigma Aldrich } \\
\text { (St. Louis, MO, } \\
\text { USA) }\end{array}$ & $>600$ & $>600$ & $>600$ & ND & ND \\
\hline Heparin & $\begin{array}{c}\text { Sulfated } \\
\text { polysaccharide }\end{array}$ & $\sim 15$ & $\begin{array}{c}\text { Sigma Aldrich } \\
\text { (St. Louis, MO, } \\
\text { USA) }\end{array}$ & $>600$ & $>600$ & $>600$ & ND & ND \\
\hline Fucoidan & $\begin{array}{c}\text { Sulfated } \\
\text { polysaccharide }\end{array}$ & $15-30$ & $\begin{array}{l}\text { Sigma Aldrich } \\
\text { (St. Louis, MO, } \\
\text { USA) }\end{array}$ & $>600$ & $>600$ & $>600$ & ND & ND \\
\hline Mannan & $\begin{array}{l}\text { Non-sulfated } \\
\text { polysaccharide }\end{array}$ & $34-62$ & $\begin{array}{c}\text { Sigma Aldrich } \\
\text { (St. Louis, MO, } \\
\text { USA) }\end{array}$ & $>600$ & $>600$ & $>600$ & ND & ND \\
\hline Chitosan & $\begin{array}{l}\text { Non-sulfated } \\
\text { polysaccharide }\end{array}$ & 190-310 & $\begin{array}{c}\text { Sigma Aldrich } \\
\text { (St. Louis, MO, } \\
\text { USA) }\end{array}$ & $>600$ & $>600$ & $>600$ & ND & ND \\
\hline Carboxymethylce & $\begin{array}{l}\text { Non-sulfated } \\
\text { lose } \\
\text { polysaccharide }\end{array}$ & $\sim 90$ & $\begin{array}{l}\text { Sigma Aldrich } \\
\text { (St. Louis, MO, } \\
\text { USA) }\end{array}$ & $>600$ & $>600$ & $>600$ & ND & ND \\
\hline Xanthan gum & $\begin{array}{l}\text { Non-sulfated } \\
\text { polysaccharide }\end{array}$ & $\begin{array}{c}2 \times 10^{3}-2 \times \\
10^{4}\end{array}$ & $\begin{array}{l}\text { Sigma Aldrich } \\
\text { (St. Louis, MO, } \\
\text { USA) }\end{array}$ & $>600$ & $>600$ & $>600$ & ND & ND \\
\hline
\end{tabular}

${ }^{\dagger} \mathrm{CC}_{50}$ : half-maximal cytotoxic concentration; ${ }^{\mathbb{I}} \mathrm{EC}_{50}$ : half-maximal effective concentration; ${ }^{*}$ therapeutic index $(\mathrm{TI})=\mathrm{CC}_{50} / \mathrm{EC}_{50} ; \S$ SARS-CoV-1 and SARS-CoV-2 Wuhan PsVs; ND: not determined.

Table 2. Synergistic activity of GRFT and CG against SARS-CoV-1 and SARS-CoV-2 PsVs.

\begin{tabular}{|c|c|c|c|c|c|}
\hline \multirow{2}{*}{\multicolumn{2}{|c|}{ Compounds }} & \multicolumn{4}{|c|}{$\mathrm{EC}_{50}{ }^{\mathrm{II}}(\mu \mathrm{g} / \mathrm{mL})$} \\
\hline & & SARS-CoV-1 & $\begin{array}{l}\text { SARS-CoV-2 } \\
\text { Wuhan }\end{array}$ & $\begin{array}{l}\text { SARS-CoV-2 } \\
\text { D614G }\end{array}$ & $\begin{array}{c}\text { SARS-CoV-2 } \\
\text { K1417N/E484K/N501Y }\end{array}$ \\
\hline \multicolumn{2}{|c|}{ GRFT } & 12.5 & 20.6 & 37.6 & 31.6 \\
\hline \multicolumn{2}{|c|}{$\mathrm{\iota}-\mathrm{CG}$} & 4.3 & 7.5 & 6.5 & 6.7 \\
\hline \multicolumn{2}{|c|}{$\lambda-\mathrm{CG}$} & 4.2 & 6.1 & 4.5 & 3.2 \\
\hline \multicolumn{2}{|c|}{ ı-CG + GRFT 1:3 ratio } & 3.8 & 2.5 & 2.7 & 1.7 \\
\hline \multicolumn{2}{|c|}{$\lambda$-CG + GRFT 1:3 ratio } & 0.7 & 3.2 & 2.8 & 1.9 \\
\hline \multicolumn{2}{|c|}{ ı-CG + GRFT 1:5 ratio } & 0.2 & 0.7 & 0.5 & 0.4 \\
\hline \multicolumn{2}{|c|}{$\lambda$-CG + GRFT 1:5 ratio } & 0.4 & 0.4 & 0.6 & 0.3 \\
\hline \multirow{2}{*}{\multicolumn{2}{|c|}{ Combination }} & \multicolumn{4}{|c|}{ CI values * } \\
\hline & & SARS-CoV-1 & $\begin{array}{l}\text { SARS-CoV-2 } \\
\text { Wuhan }\end{array}$ & $\begin{array}{l}\text { SARS-CoV-2 } \\
\text { D614G }\end{array}$ & $\begin{array}{c}\text { SARS-CoV-2 } \\
\text { K1417N/E484K/N501Y }\end{array}$ \\
\hline \multirow{3}{*}{ ı-CG + GRFT } & $\mathrm{ED}_{50}$ & ND & ND & 0.19910 & 0.28442 \\
\hline & $\mathrm{ED}_{75}$ & ND & ND & 0.11192 & 0.19067 \\
\hline & $\mathrm{ED}_{90}$ & ND & ND & 0.07208 & 0.13426 \\
\hline \multirow{3}{*}{$\lambda-\mathrm{CG}+\mathrm{GRFT}$} & $\mathrm{ED}_{50}$ & 0.61385 & 0.66908 & 0.35799 & 0.62309 \\
\hline & $\mathrm{ED}_{75}$ & 0.30337 & 0.51784 & 0.25653 & 0.43368 \\
\hline & $\mathrm{ED}_{90}$ & 0.18899 & 0.40843 & 0.19111 & 0.30924 \\
\hline
\end{tabular}

${ }^{\mathbb{I}} \mathrm{EC}_{50}$ : half-maximal effective concentration; ${ }^{*}$ combination index $(\mathrm{CI})$ : a quantitative measure of the degree of drug interaction in terms of additive effect $(C I=1)$, synergism $(C I<1)$, or antagonism $(C I>1)$ is shown for a given end point of the effect measurement; ND: not determined. 


\section{Discussions}

This synergistic in vitro activity of GRFT and CG suggests that formulations delivering combinations of GRFT and CG might be useful in preventing or treating infections caused by SARS-CoV-1 or SARS-CoV-2. In addition to the potent activity of GRFT and CG against SARS-CoV-2, CG has been shown to have activity against the common cold [21], which is caused by a variety of respiratory viruses, including coronaviruses. Clinical studies show significant reduction in severity of common cold symptoms in subjects that administered CG nasally. Furthermore, data in mice inoculated intranasally with influenza A virus in the presence of $\mathrm{\imath -CG}$, demonstrated potent activity of CG against influenza. This activity is mediated through direct binding of CG to viral particles, which inhibits viral adsorption and internalization [22].

Importantly, in vivo studies will still be required to confirm this in vitro synergistic activity in animal models. Pharmacokinetic and pharmacodynamic studies will be essential to understand the potential of this combination [23]. Our formulation will require topical administration through the upper respiratory tract contrary to other antivirals currently used to treat SARS-CoV-2 infections that require intravenous (IV) administration. One of these antivirals is remdesivir, an inhibitor of the viral RNA-dependent RNA polymerase (RdRp) that requires daily IV doses of 100 or $200 \mathrm{mg}$ [24]. The GRFT and CG combination has the advantage of using two naturally occurring agents whose safety has been thoroughly studied in different animal models and clinical studies $[13,15,18,25,26]$. The mode of action of these molecules does not require systemic adsorption, and topical application in the upper respiratory tract will interfere with the coronaviruses' attachment and entry to epithelial cells.

\section{Conclusions}

These results strongly suggest that a GRFT/CG combination could provide broadspectrum antiviral activity targeting different respiratory viruses, including a range of coronaviruses. The extensive preclinical safety data available for the GRFT and CG combination $[8,25]$ and the results shown herein support testing this combination in preclinical efficacy and toxicology models and its subsequent clinical evaluation for delivery in the upper (and possibly lower) respiratory tract.

\section{Methods}

\subsection{Cell Line and Pseudovirus Production}

The human angiotensin-converting enzyme 2 (hACE-2)-expressing HeLa cells (HeLa ACE-2) were provided by Dr. Dennis Burton (The Scripps Research Institute, La Jolla, CA, USA). SARS-CoV-1 and SARS-CoV-2 pseudoviruses (PsV) were produced following the procedure described by Schmidt et al., 2020 [27]. Plasmids containing the SARS-CoV-1 or SARSCoV-2 spike genes [pSARS-CoV1-Strunc, pSARS-CoV2-Strunc (original Wuhan strain), pSARS-CoV2-Strunc (D614G mutation), pSARS-CoV2-Strunc (K1417N/E484K/N501Y mutations)], pCRV1NHG GagPol, and pNanoLuc2AEGFP were used to produce the PsVs [27]. pCRV1NHG GagPol, pNanoLuc2AEGFP, and pSARS-CoV1-Strunc or pSARS-CoV2-Strunc plasmids were used to transfect 293T cells (ATCC, Manassas, VA, USA) seeded in 6well plates, using lipofectamine 2000 (ThermoFisher Scientific, Waltham, MA, USA). The DNA/lipofectamine 2000 mixtures were added to 293T cell monolayers and incubated for $6 \mathrm{~h}$ at $37^{\circ} \mathrm{C}, 5 \% \mathrm{CO}_{2}$, and $98 \%$ humidity. After this brief incubation, the cell monolayers were washed twice with D-PBS (ThermoFisher Scientific, Waltham, MA, USA), and DMEM (ThermoFisher Scientific, Waltham, MA, USA) with 10\% FBS (ThermoFisher Scientific, Waltham, MA, USA) and Penicillin + Streptomycin (ThermoFisher Scientific, Waltham, MA, USA) was added to each well. The plates were incubated for $48 \mathrm{~h}$ at $37^{\circ} \mathrm{C}, 5 \% \mathrm{CO}_{2}$, $98 \%$ humidity, and the cell supernatants were collected, filtered (using a $0.22 \mu \mathrm{m}$ pore size PVDF filter), aliquoted and stored at $-80^{\circ} \mathrm{C}$. The viral titers (SARS-CoV-1 PsV, SARS-CoV-2 Wuhan PsV, SARS-CoV-2 D614G PsV, and SARS-CoV-2 K1417N/E484K/N501Y PsV) were 
determined using a cell-based pseudoviral entry assay [27] and the TurboLuc ${ }^{\mathrm{TM}}$ Luciferase One-Step Glow Assay Kit (ThermoFisher Scientific, Waltham, MA, USA).

\subsection{Cytotoxicity and Antiviral Assay}

The cytotoxicity and antiviral activity were determined using the XTT [26] and the cell-based pseudoviral entry assay, respectively. Briefly, different concentrations of each compound (Table 1) were added in triplicate to HeLa ACE-2 cells seeded in clear bottom 96well microplates and then incubated at $37{ }^{\circ} \mathrm{C}, 5 \% \mathrm{CO}_{2}$, and $98 \%$ humidity for $72 \mathrm{~h}$. Tween 20 (Sigma Aldrich, St. Louis, MO, USA) was used as a positive control for cytotoxicity. XTT (ThermoFisher Scientific, Waltham, MA, USA) was added to all wells after 72-h incubation, and the absorbance was measured at $450 \mathrm{~nm}$ using a Spectramax iD3 (Molecular Devices, San Jose, CA, USA). The antiviral activity of the same compounds tested in the XTT assay was evaluated using the cell-based pseudoviral entry assay with SARSCoV-1 PsV and SARS-CoV-2 Wuhan PsV. The same concentrations/replicates of each compound tested in the XTT assay were challenged (co-treatment) with SARS-CoV-1 PsV or SARS-CoV-2 Wuhan PsV in HeLa ACE-2 cell monolayers seeded in white opaque 96-well microplates. The plates were incubated at $37{ }^{\circ} \mathrm{C}, 5 \% \mathrm{CO}_{2}$, and $98 \%$ humidity for $72 \mathrm{~h}$. The TurboLuc ${ }^{\mathrm{TM}}$ Luciferase One-Step Glow Assay (ThermoFisher Scientific, Waltham, MA, USA) was used to determine the percentage entry of the PsVs in the presence of each compound concentration versus the virus control. The half-maximal cytotoxic concentration $\left(\mathrm{CC}_{50}\right)$ and half-maximal effective concentration $\left(\mathrm{EC}_{50}\right)$ were determined for each compound, using a dose-response-inhibition analysis on GraphPad Prism v9.0.2 software (San Diego, $\mathrm{CA}, \mathrm{USA})$. The therapeutic index ( $\mathrm{TI}=\mathrm{CC}_{50} / \mathrm{EC}_{50}$ ) was calculated for each compound.

\subsection{Combination Studies}

The potential synergistic, additive, or antagonistic effect of different compounds combinations was determined by CalcuSyn v1 software (Biosoft, Cambridge, UK), which estimated the combination index (CI) values. For this purpose, equipotential combinations of GRFT and CG were evaluated in this experiment. Based on the $\mathrm{EC}_{50}$ values of each compound, ratios of 1:3 or 1:5 (CG:GRFT) were determined as optimal. Each compound alone or in combination was tested against SARS-CoV-1 PsV, SARS-CoV-2 Wuhan PsV, SARS-CoV-2 D614G PsV, and SARS-CoV-2 K1417N/E484K/N501Y PsV. The cytotoxicity and antiviral assay described in the previous section were used to evaluate the toxicity and efficacy of these combinations. The inhibitory effects for each drug alone or in combination were transferred to CalcuSyn software to estimate CI values. All compounds and combinations were tested in at least two independent experiments.

Funding: This research was funded by Population Council. Nadjet Cornejal and Claudia Melo were funded by the Maximizing Access to Research Careers (MARC) Program (NIH Grant \# 5T34GM008078-31) at Brooklyn College. Oneil Mahoney was funded by the CUNY Research Scholars Program (CRSP) and the S-STEM program at the Borough of Manhattan Community College.

Institutional Review Board Statement: Not applicable.

Informed Consent Statement: Not applicable.

Data Availability Statement: Not applicable.

Acknowledgments: The plasmids containing the SARS-CoV-1 or SARS-CoV-2 spike genes [pSARSCoV1-Strunc, pSARS-CoV2-Strunc (original Wuhan strain), pSARS-CoV2-Strunc (D614G mutation), pSARS-CoV2-Strunc (K1417N/E484K/N501Y mutations)], pCRV1NHG GagPol, and pNanoLuc2AEGFP were kindly provided by Theodora Hatziioannou and Paul Bieniasz, Rockefeller University.

Conflicts of Interest: The authors declare no conflict of interest.

\section{References}

1. WHO. Coronavirus Disease (COVID-19) Pandemic. 2021. Available online: https://www.who.int/emergencies/diseases/novelcoronavirus-2019 (accessed on 13 July 2021). 
2. Guarner, J. Three Emerging Coronaviruses in Two Decades. Am. J. Clin. Pathol. 2020, 153, 420-421. [CrossRef] [PubMed]

3. Leung, K.; Shum, M.H.; Leung, G.M.; Lam, T.T.; Wu, J.T. Early transmissibility assessment of the N501Y mutant strains of SARS-CoV-2 in the United Kingdom, October to November 2020. Eurosurveillance 2021, 26. [CrossRef] [PubMed]

4. Parker, E.P.K.; Shrotri, M.; Kampmann, B. Keeping track of the SARS-CoV-2 vaccine pipeline. Nat. Rev. Immunol. 2020, 20, 650. [CrossRef] [PubMed]

5. Plante, J.A.; Liu, Y.; Liu, J.; Xia, H.; Johnson, B.A.; Lokugamage, K.G.; Zhang, X.; Muruato, A.E.; Zou, J.; Fontes-Garfias, C.R.; et al Spike mutation D614G alters SARS-CoV-2 fitness. Nature 2021, 592, 116-121. [CrossRef] [PubMed]

6. Tegally, H.; Wilkinson, E.; Giovanetti, M.; Iranzadeh, A.; Fonseca, V.; Giandhari, J.; Doolabh, D.; Pillay, S.; San, E.J.; Msomi, N.; et al. Detection of a SARS-CoV-2 variant of concern in South Africa. Nature 2021, 592, 438-443. [CrossRef] [PubMed]

7. Hoffmann, M.; Kleine-Weber, H.; Schroeder, S.; Kruger, N.; Herrler, T.; Erichsen, S.; Schiergens, T.S.; Herrler, G.; Wu, N.H.; Nitsche, A.; et al. SARS-CoV-2 Cell Entry Depends on ACE2 and TMPRSS2 and Is Blocked by a Clinically Proven Protease Inhibitor. Cell 2020, 181, 271-280.e8. [CrossRef] [PubMed]

8. Levendosky, K.; Mizenina, O.; Martinelli, E.; Jean-Pierre, N.; Kizima, L.; Rodriguez, A.; Kleinbeck, K.; Bonnaire, T.; Robbiani, M.; Zydowsky, T.M.; et al. Griffithsin and Carrageenan Combination To Target Herpes Simplex Virus 2 and Human Papillomavirus. Antimicrob. Agents Chemother. 2015, 59, 7290-7298. [CrossRef]

9. O'Keefe, B.R.; Giomarelli, B.; Barnard, D.L.; Shenoy, S.R.; Chan, P.K.; McMahon, J.B.; Palmer, K.E.; Barnett, B.W.; Meyerholz, D.K.; Wohlford-Lenane, C.L.; et al. Broad-spectrum in vitro activity and in vivo efficacy of the antiviral protein griffithsin against emerging viruses of the family Coronaviridae. J. Virol. 2010, 84, 2511-2521. [CrossRef]

10. Kwon, P.S.; Oh, H.; Kwon, S.J.; Jin, W.; Zhang, F.; Fraser, K.; Hong, J.J.; Linhardt, R.J.; Dordick, J.S. Sulfated polysaccharides effectively inhibit SARS-CoV-2 in vitro. Cell Discov. 2020, 6, 50. [CrossRef]

11. Morokutti-Kurz, M.; Froba, M.; Graf, P.; Grosse, M.; Grassauer, A.; Auth, J.; Schubert, U.; Prieschl-Grassauer, E. Iota-carrageenan neutralizes SARS-CoV-2 and inhibits viral replication in vitro. PLOS ONE 2021, 16, e0237480.

12. Moulaei, T.; Alexandre, K.B.; Shenoy, S.R.; Meyerson, J.R.; Krumpe, L.R.; Constantine, B.; Wilson, J.; Buckheit, R.W., Jr.; McMahon, J.B.; Subramaniam, S.; et al. Griffithsin tandemers: Flexible and potent lectin inhibitors of the human immunodeficiency virus. Retrovirology 2015, 12, 6. [CrossRef]

13. Lee, C. Griffithsin, a Highly Potent Broad-Spectrum Antiviral Lectin from Red Algae: From Discovery to Clinical Application. Mar. Drugs 2019, 17, 567. [CrossRef]

14. O'Keefe, B.R.; Vojdani, F.; Buffa, V.; Shattock, R.J.; Montefiori, D.C.; Bakke, J.; Mirsalis, J.; d'Andrea, A.L.; Hume, S.D.; Bratcher, B.; et al. Scaleable manufacture of HIV-1 entry inhibitor griffithsin and validation of its safety and efficacy as a topical microbicide component. Proc. Natl. Acad. Sci. USA 2009, 106, 6099-6104. [CrossRef]

15. Lusvarghi, S.; Bewley, C.A. Griffithsin: An Antiviral Lectin with Outstanding Therapeutic Potential. Viruses 2016, 8, 296. [CrossRef] [PubMed]

16. Buck, C.B.; Thompson, C.D.; Roberts, J.N.; Muller, M.; Lowy, D.R.; Schiller, J.T. Carrageenan is a potent inhibitor of papillomavirus infection. PLoS Pathog. 2006, 2, e69. [CrossRef] [PubMed]

17. Rodriguez, A.; Kleinbeck, K.; Mizenina, O.; Kizima, L.; Levendosky, K.; Jean-Pierre, N.; Villegas, G.; Ford, B.E.; Cooney, M.L.; Teleshova, N.; et al. In vitro and in vivo evaluation of two carrageenan-based formulations to prevent HPV acquisition. Antivir. Res. 2014, 108, 88-93. [CrossRef]

18. Friedland, B.A.; Hoesley, C.J.; Plagianos, M.; Hoskin, E.; Zhang, S.; Teleshova, N.; Alami, M.; Novak, L.; Kleinbeck, K.R.; Katzen, L.L.; et al. First-in-Human Trial of MIV-150 and Zinc Acetate Coformulated in a Carrageenan Gel: Safety, Pharmacokinetics, Acceptability, Adherence, and Pharmacodynamics. JAIDS J. Acquir. Immune Defic. Syndr. 2016, 73, 489-496. [CrossRef]

19. Hebar, A.; Koller, C.; Seifert, J.M.; Chabicovsky, M.; Bodenteich, A.; Bernkop-Schnurch, A.; Grassauer, A.; Prieschl-Grassauer, E. Non-clinical safety evaluation of intranasal iota-carrageenan. PLoS ONE 2015, 10, e0122911. [CrossRef] [PubMed]

20. Food and Drug Administration (FDA). CFR—Code of Federal Regulations. Title 21: Food and Drugs. Electronic Code Federal Regulation; FDA: Silver Spring, MD, USA, 2014.

21. Koenighofer, M.; Lion, T.; Bodenteich, A.; Prieschl-Grassauer, E.; Grassauer, A.; Unger, H.; Mueller, C.A.; Fazekas, T. Carrageenan nasal spray in virus confirmed common cold: Individual patient data analysis of two randomized controlled trials. Multidiscip. Respir. Med. 2014, 9, 57. [CrossRef] [PubMed]

22. Leibbrandt, A.; Meier, C.; Konig-Schuster, M.; Weinmullner, R.; Kalthoff, D.; Pflugfelder, B.; Graf, P.; Frank-Gehrke, B.; Beer, M.; Fazekas, T.; et al. Iota-carrageenan is a potent inhibitor of influenza A virus infection. PLoS ONE 2010, 5, e14320. [CrossRef] [PubMed]

23. Shikov, A.N.; Flisyuk, E.V.; Obluchinskaya, E.D.; Pozharitskaya, O.N. Pharmacokinetics of Marine-Derived Drugs. Mar. Drugs 2020, 18, 557. [CrossRef] [PubMed]

24. Sun, D. Remdesivir for Treatment of COVID-19: Combination of Pulmonary and IV Administration May Offer Aditional Benefit. AAPS J. 2020, 22, 77. [CrossRef]

25. Derby, N.; Lal, M.; Aravantinou, M.; Kizima, L.; Barnable, P.; Rodriguez, A.; Lai, M.; Wesenberg, A.; Ugaonkar, S.; Levendosky, K.; et al. Griffithsin carrageenan fast dissolving inserts prevent SHIV HSV-2 and HPV infections in vivo. Nat. Commun. 2018,9 , 3881. [CrossRef] [PubMed] 
26. Fernandez-Romero, J.A.; Abraham, C.J.; Rodriguez, A.; Kizima, L.; Jean-Pierre, N.; Menon, R.; Begay, O.; Seidor, S.; Ford, B.E.; Gil, P.I.; et al. Zinc acetate/carrageenan gels exhibit potent activity in vivo against high-dose herpes simplex virus 2 vaginal and rectal challenge. Antimicrob. Agents Chemother. 2012, 56, 358-368. [CrossRef] [PubMed]

27. Schmidt, F.; Weisblum, Y.; Muecksch, F.; Hoffmann, H.H.; Michailidis, E.; Lorenzi, J.C.C.; Mendoza, P.; Rutkowska, M.; Bednarski, E.; Gaebler, C.; et al. Measuring SARS-CoV-2 neutralizing antibody activity using pseudotyped and chimeric viruses. J. Exp. Med. 2020, 217, e20201181. [CrossRef] [PubMed] 